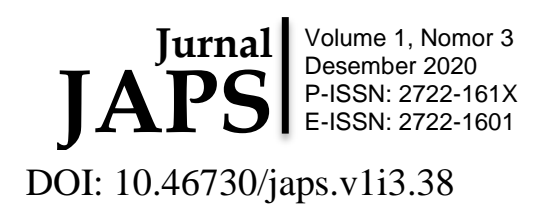

\title{
Kinerja Dinas Pemberdayaan Masyarakat dan Desa Kabupaten Gianyar dalam Meningkatkan Kesejahteraan Masyarakat
}

\author{
${ }^{1}$ Ni Putu Anik Prabawati; ${ }^{2}$ Ni Wayan Supriliyani \\ ${ }^{12}$.Program Studi Administrasi Publik, Fakultas Ilmu Sosial dan Ilmu Politik, Universitas \\ Udayana \\ Email : ${ }^{1}$ Prabawati@unud.ac.id, ${ }^{2}$ Supriliyani@unud.ac.id
}

\begin{abstract}
Kata kunci
Abstrak

Penelitian ini bertujuan untuk mengetahui kinerja dari Dinas Pemberdayaan Masyarakat dan Desa Kabupaten Gianyar dalam meningkatkan kesejahteraan masyarakat di lingkungan kabupaten Gianyar. Mengetahui program-program yang dilaksanakan dalam memperdaya masyarakat serta realisasi program tersebut. Dalam mendapatkan data-data tersebut, maka penelitian ini menggunakan metode penelitian kualitatif, dengan menggunakan observasi, wawancara, dan dokumentasi. Hasil penelitian menyatakan bahwa Dinas Pemberdayaan Masyarakat dan desa telah melaksanakan kinerja sesuai dengan ketentuan indikator pengukuran kinerja dalam memberdayakan masyarakat. Terdapat berbagai jenis program pengembangan dan pemberdayaan yang dilaksanakan untuk mendorong perkembangan industri kreatif dalam masyarakat. Simpulan dari penelitian ini ialah kinerja Dinas Pemberdayaan Masyarakat dan Desa sudah efektif dalam meningkatkan kesejahteraan masyarakat di lingkungan Kabupaten Gianyar. Implikasi Penelitian ini ialah agar dapat dijadikan acuan oleh para pelaksana kegiatan pemberdayaan dalam memaksimalkan potensi daerahnya masing-masing.
\end{abstract}

Keywords

Community;

Empowerment; Welfare

\begin{abstract}
This study aims to determine the performance of the Gianyar Regency Community and Village Empowerment Service in improving the welfare of the community in the Gianyar regency. Knowing the programs implemented in deceiving the community and the realization of these programs. In obtaining these data, this study uses qualitative research methods. The results of the study state that the Community and Village Empowerment Service has implemented performance in accordance with the provisions of the performance measurement indicators in empowering the community. There are various types of development and empowerment programs implemented to encourage the development of the creative industry in society. The conclusion of this study is that the performance of the Community and Village Empowerment Service has been effective in improving the welfare of the community in Gianyar Regency.
\end{abstract}




\section{Pendahuluan}

Pemerintah Daerah memiliki peran yang cukup penting dalam membantu peningkatan pembangunan nasional dalam jangkauan wilayah administrastifnya. Hal tersebut dikarenakan oleh pemerintah daerah memiliki hak otonom untuk mengelola dan mengembangkan potensi yang ada di daerahnya baik itu sumber daya alam maupun sumber daya manusia. Hak otonom memberikan peluang bagi pemerintah daerah untuk dapat meningkatkan pembangunan di wilayahnya dengan harapan dapat meningkatkan kesejahteraan masyarakat di lingkup daerah tersebut. Dalam rangka peningkatan pembangunan daerah terdapat beberapa hal yang biasa dilaksanakan oleh pemerintah daerah yakni perbaikan serta pembuatan sarana-prasarana penunjang aktivitas perekonomian, pendidikan, kesehatan serta kebutuhan dasar lainnya. Selain itu peningkatan pembangunan daerah juga dapat dilaksanakan melalui pemberdayaan masyarakat, dengan tujuan agar masyarakat dapat memainkan peran sentral dalam meningkatkan layanan dan pengembangan mata pencaharian lokal. Pemberdayaan masyarakat biasanya menyasar tingkatan terkecil di pemerintahan yaitu Desa. Kewenangan Desa meliputi kewenangan di bidang penyelenggaraan Pemerintahan Desa, pelaksanaan Pembangunan Desa, pembinaan kemasyarakatan Desa, dan pemberdayaan masyarakat Desa berdasarkan prakarsa masyarakat, hak asal usul, dan adat istiadat Desa.

Undang-undang No. 6 Tahun 2014 tentang Desa menjelaskan mengenai pengertian dari Pemberdayaan masyarakat desa yakni upaya mengembangkan kemandirian dan kesejahteraan masyarakat dengan meningkatkan pengetahuan, sikap, keterampilan, perilaku, kemampuan, kesadaran, serta memanfaatkan sumber daya melalui penetapan kebijakan, program, kegiatan, dan pendampingan yang sesuai dengan esensi masalah dan prioritas kebutuhan masyarakat Desa. Tujuan dari pemberdayaan masyarakat ini ialah untuk meningkatkan kesejahteraan masyarakat melalui pemberian pelatihan ketrampilan yang nantinya dapat mereka manfaatkan untuk memperoleh mata pencaharian serta bantuan dana yang dapat digunakan untuk mengembangkan usaha masyarakat.

Kabupaten Gianyar merupakan salah satu kawasan strategis pariwisata yang ada di Provinsi Bali. Namun, walaupun merupakan kawasan pariwisata, hal tersebut tidak menjamin adanya pemerataan kesejahteraan masyarakat di daerah tersebut. Menurut data statistik, persentase jumlah penduduk miskin yang ada di Kabupaten Gianyar belum mengalami perubahan yang signifikan. Berdasarkan atas latar belakang diatas peneliti ingin meneliti lebih lanjut mengenai kinerja dari Dinas Pemberdayaan Masyarakat dan Desa Kabupaten dalam rangka meningkatkan efektifitas pelaksanaan pemberdayaan masyarakat dan desa sehingga mampu untuk menurunkan nilai kemiskinan dan berdampak pada peningkatan kesejahteraan masyarakat di Kabupaten Gianyar. Judul yang digunakan dalam penelitian ini ialah "Kinerja Dinas Pemberdayaan dan Desa Kabupaten Gianyar dalam Meningkatkan Kesejahteraan Masyarakat".

Sesuai dengan latar belakang diatas, rumusan masalah yang diangkat dalam penelitian ini ialah Bagaimana kinerja Dinas Pemberdayaan Masyarakat dan Desa Kabupaten Gianyar dalam meningkatkan kesejahteraan masyarakat di Kabupaten Gianyar?. Sesuai dengan rumusan masalah tersebut, maka tujuan dari penelitian ini adalah untuk mengetahui pelaksanaan kinerja Dinas Pemberdayaan Masyarakat dan Desa Kabupaten Gianyar dalam meningkatkan kesejahteraan masyarakat. 


\section{Metode Penelitian}

Metode Penelitian yang digunakan dalam penelitian ini ialah Metode Penelitian Kualitatif. Metode penelitian kualitatif ialah sebuah metode yang digunakan dalam mengungkapkan permasalahan di kehidupan kerja organisasi Pemerintah, swasta, kemasyarakatan, kepemudaan, perempuan, olahraga, seni dan budaya, sehingga dapat dijadikan suatu kebijakan untuk dilaksanakan demi kesejahteraan bersama. Penelitian kualitatif bertujuan untuk mengembangkan konsep sensitivitas pada masalah yang dihadapi, menerangkan realitas yang berkaitan dengan penelusuran teori dari bawah (grounded theory) dan mengembangkan pemahaman terhadap fenomena yang dihadapi. Penelitian deskriptif kualitatif digunakan untuk mengetahui nilai variable mandiri, baik satu atau lebih tanpa membuat perbandingan atau menghubungkan satu variabel dengan variabel yang lain. Metode ini dipilih karena penelitian ini betujuan untuk menyajikan informasi-informasi mengenai Kinerja Dinas Pemberdayaan Masyarakat dan Desa dalam meningkatkan kesejahteraan masyarakat di Kabupaten Gianyar. Penelitian ini berlokasi di Kantor Dinas Pemberdayaan Masyarakat dan Desa Kabupaten Gianyar yang beralamat di Jalan By. Pass Dharma Giri Gianyar.

Teknik Pengumpulan data dilakukan dengan cara Observasi Lapangan, Wawancara Mendalam, Studi Pustaka dan Studi Dokumentasi (Kusmayadi, 2000:84). Teknik Penentuan Informan dilakukan dengan metode snowball sampling. Snowball sampling adalah cara yang efektif untuk membangun kerangka pengambilan sampel yang mendalam, dalam populasi yang relatif kecil, yang masing-masing orang cenderung melakukan hubungan satu dan lainnya. Teknik analis data yang digunakan yaitu teknik analis data Kualitatif Model Miles and Huberman (Sugiyono, 2007:337) dengan Tahapan meliputi (1) Pengumpulan Data, (2) Reduksi Data, (3) Penyajian Data, (4) Verifikasi atau Penyimpulan Data.

\section{Hasil Dan Pembahasan}

\section{Kinerja Dinas Pemberdayaan Masyarakat dan Desa Kabupaten Gianyar}

Prioritas Pembangunan Daerah pada dasarnya merupakan program yang menjadi kebutuhan mendesak sesuai dengan potensi, dana, tenaga dan kemampuan managerial yang dimiliki. Program prioritas Pembangunan Pemerintah Daerah Kabupaten Gianyar 5 (lima) tahun kedepan di fokuskan pada: (1) Pembangunan Kesehatan, KB dan Pemberdayaan Perempuan, (2) Pembangunan Pendidikan (3) Pembangunan Kesejahteraan Pemerataan Ekonomi (4) Pembangunan Pariwisata (5) Pembangunan Insfrastruktur (6) Pembangunan Pemerintahan, Penataan Ruang, dan Pengelolaan Lingkungan Hidup. Pembangunan bidang pemberdayaan termasuk kedalam prioritas program Pembangunan kesejahteraan pemerataan ekonomi yang difokuskan pada program-program Pembangunan Terpadu bagi masyarakat miskin dengan bekerja sama dengan pemerintah Provinsi dan dunia usaha. Sesuai dengan Visi dan Misi Kepala Daerah dan Wakil Kepala Daerah Kabupaten Gianyar yang tertuang dalam RPJMD Kabupaten Gianyar Tahun 2018-2023 yang menjadi Visi 5 Tahun kedepan adalah : "Terwujudnya Masyarakat Gianyar yang Bahagia, Sejahtera, Aman dan Damai, Mandiri, Berintegritas Berlandaskan Tri Hita Karana melalui Pola Pembangunan Nasional Semesta Berencana". Sedangkan Misi dari Pemerintah Kabupaten Gianyar ialah (1) Membangun pertanian yang produktif, efisien dan mandiri. (2) Membangun pariwisata yang inklusif dan berbasis budaya. (3) pertumbuhan ekonomi yang berkualitas berwawasan lingkungan. (4) Mengembangkan SDM yang berintegritas dan berdaya saing tinggi. (5) Mewujudkan penguatan desa adat yang bertumpu pada nilai- 
nilai adat, buadya dan Agama Hindu. (6) Meningkatkan kuantitas dan kualitas pelayanan publik.

Peran Dinas Pemberdayaan Masyarakata dan Desa dalam misi tersebut berkaitan dengan misi ketiga yaitu pertumbuhan ekonomi yang berkualitas berwawasan lingkungan, serta misi kelima yaitu Mewujudkan penguatan desa adat yang bertumpu pada nilai-nilai adat, budaya dan Agama Hindu. Dalam rangka pencapaian kedua misi tersebut, maka Dinas Pemberdayaan Masyarakat dan Desa Kabupaten Gianyar membuat 15 (lima belas) program yakni sebagai berikut: (1) Program Pelayanan Administrasi Perkantoran, (2) Program Peningkatan Sarana dan Prasarana Aparatur, (3) Program Peningkatan Pengembangan Sistem Pelaporan Capaian Kinerja dan Keuangan, (4) Program Peningkatan Keberdayaan Masyarakat Perdesaan, (5) Program Pemberdayaan Kawasan Pedesaan, (6) Program Peningkatan Partisipasi Masyarakat Dalam Membangun Desa, (7) Kapasitas Aparatur Pemerintahan Desa, (8) Program Penataan Daerah Otonomi Baru, (9) Program Pengembangan Lembaga Ekonomi Pedesaan, (10) Program Pemberdayaan Masyarakat melalui gerakan PKK, (11) Program Pengembangan Potensi Desa/Kelurahan, (12) Program Pembinaan dan Fasilitasi Pengelolaan Keuangan Desa, (13) Program Pemberdayaan Pengelolaan SDA TTG Desa/Kelurahan, (14) Program Pengembangan Sarana Prasarana Dasar Perdesaan, (15) Program Peningkatan Keswadayaan Masyarakat Perdesaan.

\section{Analisis Kinerja Dinas Pemberdayaan Masyarakat dan Desa Kabupaten Gianyar dalam Meningkatkan Kesejahteraan Masyarakat}

Penilaian kinerja merupakan suatu kegiatan yang sangat penting karena dapat digunakan sebagai ukuran keberhasilan suatu organisasi dalam mencapai misinya. Untuk organisasi pelayanan publik, informasi mengenai kinerja tentu sangat berguna untuk menilai seberapa jauh pelayanan yang diberikan oleh organisasi itu memenuhi harapan dan memuaskan jasa (Dwiyanto, 2006:50). Menurut Agus Dwiyanto indikator kinerja dalam mengukur kinerja birokrasi publik, yaitu:

\section{Produktivitas}

Konsep produktivitas tidak hanya mengukur tingkat efisiensi, tetapi juga efektivitas pelayanan. Efisiensi merupakan suatu ukuran dalam membandingkan penggunaan input yang direncanakan dibandingkan dengen output yang terlaksana. Sementara, efektivitas menunjukkan sejauh mana target dapat tercapai, baik secara kuantitas maupun waktu. Input dalam hal ini adalah kegiatan yang direncanakan, sumber daya manusia (SDM) selaku pelaksana layanan di Dinas Pemberdayaan Masyarakat dan Desa Kabupaten Gianyar. sedangkan yang menjadi output adalah kegiatan yang telah tereaslisasi sesuai dengan target capaian. Bentuk produktivitas Dinas Pemberdayaan Masyarakat dan Desa Kabupaten Gianyar ialah dari 15 Program yang direncanakan sesuai RENJA, 11 Program telah terealisasi diatas $90 \%$, sedangkan 4 program realisasinya masih dibawah 90\% yaitu (1) Program Peningkatan Sarana dan Prasarana Aparatur, (2) Program Peningkatan Pengembangan Sistem Pelaporan Capaian Kinerja dan Keuangan, (3) Program Penataan Daerah Otonomi Baru, (4) Program Pemberdayaan Masyarakat Melalui Gerakan PKK. Adapun hal yang menjadi penyebab capaian yang belum maksimal tersebut ialah sumber daya manusia di lingkungan Dinas Pemberdayaan Masyarakat dan Desa Kabupaten yang masih terbatas sedangkan lingkup kerjanya 
cukup luas sehingga memerlukan waktu yang cukup panjang dalam merealisasikan program tersebut.

\section{Kualitas Layanan}

Banyak pandangan negatif yang terbentuk mengenai organisasi publik muncul karena ketidakpuasan masyarakat terhadap kualitas layanan yang diterima dari organisasi publik. Akses informasi, sarana dan prasarana serta kepuasan masyarakat terhadap layanan dapat dijadikan indikator kinerja untuk menilai kualitas Layanan di Dinas Pemberdayaan Masyarakat dan Desa Kabupaten Gianyar. Dilihat dari akses informasi Dinas Pemberdayaan Masyarakat dan Desa telah memiliki Website resmi yang dapat diakses melalui link berikut ini http://dinaspmd.gianyarkab.go.id/. Namun informasi yang tersedia masih belum begitu lengkap. Selain itu media komunikasi yang digunakan untuk berkoordinasi dengan pemerintah desa yaitu melalui media sosial Whatsapp group, dimana whatsapp group tersebut beranggotakan para kepala desa di lingkungan kabupaten gianyar. Melalui media ini staff Dinas pemberdayaan Masyarakat dan Desa menyampaikan informasi serta kebijakan terbaru terkait dengan pemberdayaan desa dan masyarakat. Terkait dengan sarana dan prasarana layanan masih sangat terbatas, contohnya tidak ada loket pelayanan, ruang tunggu, serta atribut-atribut pelayanan lainnya. Hal tersebut disebabkan oleh program kerja dari Dinas tersebut sebagaian besar terjun kelapangan dan langsung melaksanakan eksekusi kinerja dilapangan, sehingga mereka tidak melaksanakan pelayanan dikantor. Namun, apabila terdapat pihak desa maupun masyarakat yang ingin berkonsultasi mereka langsung diarahkan pada bidangbidang yang bertanggungjawab terhadap hal tersebut. Sedangkan terkait dengan Kepuasan Masyarakat terhadap pelayanan, pihak Dinas Pemberdayaan Masyarakat dan Desa Kabupaten Gianyar belum pernah melaksanakan survey kepuasan masyarakat, sehingga tidak terdapat informasi yang pasti mengenai tingkat kepuasan masyarakat dan desa terhadap kinerja Dinas Pemberdayaan Masyarakat dan Desa Kabupaten Gianyar.

\section{Responsivitas}

Responsivitas adalah kemampuan organisasi untuk mengenali kebutuhan masyarakat, menyusun agenda dan prioritas pelayanan, mengembangkan program-program pelayanan publik sesuai dengan kebutuhan dan aspirasi masyarakat. Bentuk Responsivitas Dinas Pemberdayaan Masyarakat dan Desa Kabupaten Gianyar ini ialah pihak dinas rutin melaksanakan kegiatan pertemuan dengan kepala desa dan tokoh masyarakat di lingkungan kabupaten gianyar. Agenda pertemuan ini ialah diskusi dengan para kepala desa terkait dengan pelaksanaan pemberdayaan di desa, serta menyampaikan kendala yang dihadapi dalam pelaksanaan pemberdayaan di desa. Hasil pertemuan tersebut akan dijadikan acuan untuk menyusun rencana kerja kedepannya.

\section{Responsibilitas}

Responsibilitas menjelaskan apakah pelaksanaan kegiatan organisasi publik itu dilakukan sesuai dengan pirnsip-prinsip administrasi yang benar, baik yang eksplisit maupun implisit. Bentuk Responsibilitas Dinas Pemberdayaan Masyarakat dan Desa Kabupaten Gianyar ini ialah setiap program dan kegiatan yang dibuat dan direalisasi telah sesuai dengan ketentuan perundang-undang dan berorientasi kepada Visi dan Misi dari Pemerintah kabupaten Gianyar. Dalam menjalankan program di desa, pihak dinas juga melakukan koordinasi dengan tenaga Ahli dan Tim Pendamping Desa tingkat 
kementerian, sehingga dari kerjasama ini diharapkan akan menghasilkan output yang maksimal sesuai target capaian.

\section{Akuntabilitas}

Konsep akuntabilitas publik digunakan untuk melihat sejauhmana kebijakan dan kegiatan organisasi publik tersebut direaliasikan sesuai dengan target capaian yang diharapkan. Dalam hal ini pertanggungjawaban dibuat secara internal maupun eksternal. Bentuk Akuntabilitas Dinas Pemberdayaan Masyarakat dan Desa Kabupaten Gianyar ini ialah membuat laporan pertanggungjawaban setiap tahun sekali yang dihimpun dari laporan pertanggung jawaban dari masing-masing desa yang menjadi obyek pemberdayaan. Laporan dari desa tersebut kemudian dibandingkan dengan Rencana Kerja dinas, untuk melihat seberapa besar presentase target capaian. Laporan pertanggungjawaban tersebut kemudian disampaikan ke Bupati, dilanjutkan ke Gubernur hingga sampai ke Kementrian.

\section{Kesimpulan}

Kesimpulan dari Hasil Penelitian terkait Kinerja Dinas Pemberdayaan Masyarakat dan Desa Kabupaten Gianyar dalam meningkatkan kesejahteraan masyarakat di Kabupaten Gianyar yakni Dinas Pemberdayaan Masyarakat dan Desa Kabupaten Gianyar sudah melaksanakan kinerja yang baik pada indikator Responsivitas, Responsibilitas dan Akuntabilitas. Sedangkan pada indikator Produktivitas dan Kualitas Layanan masih perlu dilakukan peningkatan kinerja. Implikasi Penelitian ini ialah agar dapat dijadikan acuan oleh para pelaksana kegiatan pemberdayaan dalam memaksimalkan potensi daerahnya masing-masing. Pengembangan hasil penelitian ini nantinya yaitu berupa rekomendasi kepada Dinas Pemberdayaan Masyarakat dan Desa Kabupaten Gianyar terkait dengan peningkatan efektifas kinerja pemberdayaan.

\section{Daftar Pustaka}

Agus Dwiyanto, 2006, Mewujudkan Good Geovernance Melalui Pelayanan Public. Yogyakarta: UGM Press.

Kusmayadi dan Endar Sugiarto. 2000. Metodologi Penelitian dalam Bidang Kepariwisataan. Jakarta: PT.Gramedia Pustaka Utama.

Sugiyono. 2007. Metode Penelitian Kuantitatif Kualitatif dan R\&D. Bandung: Alfabeta. Undang-undang No. 6 Tahun 2014 tentang Desa

Peraturan Daerah Kabupaten Gianyar Nomor 5 Tahun 2016 tentang Pembentukan Susunan Perangkat Daerah Dinas Pemberdayaan Masyarakat dan Desa. 